\title{
O diálogo é a missão: o desafio missionário diante do pluralismo religioso
}

\author{
Dialogue is the mission: \\ the missionary challenge before religious pluralism
}

Alonso S. Gonçalves*

\begin{abstract}
Resumo
Este artigo se propõe a pensar a relação que se dá entre missão e diálogo inter-religioso. Para isso, num primeiro instante, aborda os principais autores que pensam a relação entre pluralismo religioso, missão e diálogo inter-religioso, no campo católico e protestante. Em sequência, olha-se para as contribuições de Paulo Freire e Kwok Pui-Lan para a noção de diálogo e Jürgen Moltmann para a concepção de missão. Com isso, espera-se responder, dentre outras perguntas, a seguinte questão: seria possível deslocar o conceito de missão para uma realidade marcada por desigualdades e problemas sistêmicos? Estaria nessa realidade uma conjunção possível entre missão e diálogo inter-religioso?
\end{abstract}

\section{Palavras-chave}

Missão. Diálogo Inter-religioso. Pluralismo Religioso.

\begin{abstract}
This article proposes to think about the relationship between mission and interreligious dialogue. For this, in a first moment, it approaches the main authors who think the relation between religious pluralism, mission and interreligious dialogue, in the catholic and Protestant field. In sequence, one looks at the contributions of Paulo Freire and Kwok Pui-Lan to the notion of dialogue and Jürgen Moltmann for the conception of mission. With this, it is expected to answer, among other questions, the following question: could it be possible to move the concept of mission to a reality marked by systemic inequalities and problems? Is this a possible conjunction between mission and interreligious dialogue?
\end{abstract}

\section{Keywords}

Mission. Interreligious Dialogue. Religious Pluralism.

[Texto recebido em novembro de 2017 e aceito em julho de 2018, com base na avaliação cega por pares realizada por pareceristas ad hoc]

* Doutorando em Ciências da Religião. Mestre em Ciências da Religião (2014). Licenciado em Filosofia (2006). Bacharel em Teologia (2004). Realiza estudos, com o apoio da Fundação de Amparo à Pesquisa do Estado de São Paulo (FAPESP) - Processo n.. 2017/09589-8) na Universidade Metodista de São Paulo, pesquisando Teologia das Religiões e Diálogo Inter-religioso a partir da Teologia Protestante. E-mail: alonso3134@hotmail.com 


\section{Introdução}

O tema da missão na América Latina está relacionado diretamente com a questão da colonização. A colonização, é vista como um ato, em si, de extrema violência. A subalternidade, a violação cultural e religiosa, estão presentes no contexto da conquista. ${ }^{1} \mathrm{E}$ mesmo um Bartolomeu de Las Casas, com uma certa empatia pelos índios, pensou, agiu e protestou como um colonizador. Quando Tzvetan Todorov faz uma leitura da conquista da América Latina, não poupa críticas à Las Casas e sua visão religiosa colonizadora: “Las Casas ama os índios. E é cristão. (...) Será que é possível amar realmente alguém ignorando sua identidade, vendo, em lugar dessa identidade, uma projeção de si mesmo ou de seu ideal? (...) Não se corre o risco de querer transformar o outro em nome de si mesmo?" .2 A missão desenvolvida quando da conquista foi marcada pela perspectiva eurocêntrica, uma visão de mundo eugênica, onde o discurso civilizador estava de mãos dadas com a religião e a espada. A carta de Pero Vaz de Caminha, apressadamente, julga que os índios são inocentes e que logo seriam cristãos. Essa conclusão se dá "porque eles não têm nem entendem em nenhuma crença". ${ }^{3} \mathrm{O}$ que se confirmou ser uma falácia, porque não demorou muito para que as primeiras missões cristãs percebessem "que os índios não só tinham suas crenças, ao contrário do que se pensava Caminha, como também não estavam dispostos a abrir mão delas facilmente". ${ }^{4} \mathrm{O}$ projeto missionário, tanto católico quanto protestante, em períodos históricos distintos, não levou em consideração a complexidade cultural dos povos latino-americanos. Se evangelizou colonizando e colonizou violentando.

Não sem razão, que o paradigma missionário centrado na colonialidade, vem sendo questionado e revisitado criticamente. ${ }^{5}$ Missiólogos e pesquisadores, estão cada vez mais afinados no mesmo tom, qual seja, que não é mais possível promover um projeto missionário de encobrimento do outro. Se antes a relação missão e colonização foi preponderante, agora é possível falar em missão e descolonização. Essa perspectiva em missiologia foi possível, dentre outros fatores, aos estudos pós-coloniais. ${ }^{6}$ Com uma nova

1 Leonardo Boff faz uma análise desse processo em: BOFF, Leonardo. América Latina: da conquista à nova evangelização. 3.ed. São Paulo: Ática, 1992.

2 TODOROV, Tzvetan. A conquista da América: a questão do outro. 4.ed. São Paulo: Martins Fontes, 2011. p. 245.

3 WIRTH, Lauri E. Protestantismos latino-americanos: entre o imaginário eurocêntrico e as culturas locais. In: FERREIRA, João C. L. (Org.). Novas perspectivas sobre o protestantismo brasileiro. São Paulo: Fonte Editorial/Paulinas, 2009. p. 19.

4 WIRTH, 2009, p. 19.

5 Analzira Nascimento, missióloga de tendência conservadora, produziu uma pesquisa de doutorado em que questiona esse paradigma colonizador no projeto missionário europeu e estadunidense na América Latina: NASCIMENTO, Analzira. Evangelização ou colonização?: o risco de fazer missão sem se importar com o outro. Viçosa: Ultimato, 2015.

6 Autores como Edward Said e Walter Mignolo têm sido referências nessa temática, além de outros de igual destaque. O primeiro pensando a ocidentalização como sistema cultural de dominação no Oriente; o segundo olhando para a América Latina e o projeto colonizador gerador de subalternidades. 
perspectiva cultural emergente, foi possível perceber a necessidade de avançar na descolonialidade 7 de mentes como ponto de partida para se pensar na missão dentro desse novo contexto cultural e teológico. A partir disso, “a missão precisa ser pensada dentro desse projeto mais amplo de repensar-nos e de repensar o mundo em que vivemos, superando a mentalidade colonial que nos habita e que deixou suas marcas profundas na reflexão teológica". ${ }^{8} \mathrm{O}$ desafio da tarefa missionária está lançado, (primeiro) quando se procura repensar o conceito de missão a partir da descolonização, mas também (segundo) quando a pluralidade religiosa se constitui como um fato incontestável. Um ponto é admitir que o conceito de missão não cabe mais a partir do projeto colonizador; outra questão, diferente, no nosso entender, é questionar o lugar da missão diante do pluralismo religioso. É possível, ainda, pensar em missão, em sua vertente evangelizadora, depois de admitir que o colonialismo impregnou com o seu ethos o modo de ser cristão na América Latina? Não sendo mais possível essa perspectiva de missão, a segunda questão, que envolve o pluralismo religioso, se faz ainda mais premente: "O que pode significar a missão quando estamos convencidos de que Deus se revela de múltiplas formas nas diferentes religiões?". 9 Lidar com essa questão envolve, naturalmente, uma série de olhares dentro das ciências humanas. Há o olhar antropológico, quando procura entender o desenvolvimento de uma determinada cultura e sua religiosidade, demonstrando a impossibilidade de não haver relação entre cultura e religião; o olhar sociológico quando capta a construção social com suas regras, costumes e leitura do ambiente social. Aqui privilegiaremos o olhar teológico, cientes que o olhar das Ciências da Religião se faz necessário, principalmente quando postulados da teologia, como revelação e salvação, por exemplo, são inegociáveis quando em diálogo com outras tradições religiosas.

A partir dessas considerações iniciais, procuraremos levantar algumas questões que envolvem a noção de missão e diálogo inter-religioso, tendo como premissa o pluralismo religioso. Com isso, perguntamos:

1. É possível pensar em missão, em seu aspecto evangelizador, quando o pluralismo religioso é levado em consideração? Há possibilidade de conjugação entre essas duas percepções?

2. Como se daria uma percepção de missão que acolhesse o diálogo inter-religioso? É possível pensar em missão quando o primeiro objetivo não é "converter" o outro?

3. Seria possível deslocar o conceito de missão para uma realidade marcada por desigualdades e problemas sistêmicos que, peremptoriamente, marginalizam os

7 Estamos cientes da distinção entre "colonialismo" e "colonialidade". Enquanto o primeiro termo se refere à dominação político-econômica de alguns povos sobre outros; o segundo termo se refere à permanência do imaginário colonial. Colonialismo é anterior à colonialidade, mas o segundo é a tentativa de perpetuação do primeiro. SILVA, Sílvia R. L. Identidade, unidade e missão: des-colonização e cuidado, paradigmas da missão. In: GIESE, Nilton (Org.). Missão e evangelização na América Latina e Caribe. São Leopoldo: Sinodal, 2012. p. 118.

8 SILVA, 2012, p. 118.

9 SILVA, 2012, p. 120. 
economicamente inválidos? Estaria nessa realidade uma conjunção possível entre missão e diálogo inter-religioso?

Procuraremos tratar essas questões elencadas a partir de alguns autores e autoras. Alguns desses autores não se conectam diretamente, com essa temática, e essa será nossa tarefa. Para o que propomos na relação missão e diálogo, tendo como pano de fundo o pluralismo religioso, as contribuições da teóloga Kwok Pui-Lan serão valorizadas, uma vez que sua leitura das religiões passa pelo envolvimento de pessoas e não, precisamente, por instituições religiosas - "as conversações e interações estão acontecendo entre pessoas que pertencem a credos, e não entre religiões em si, entre religiões como sistemas de crenças e práticas". ${ }^{10}$ Além dela, o conceito de diálogo presente nas reflexões de Paulo Freire serão utilizados. No campo teológico, o teólogo alemão Jürgen Moltmann entrará no debate por desenvolver uma concepção de missão centrada no testemunho do Reino de Deus presente na caminhada de Jesus de Nazaré e suas consequências para a Igreja.

\title{
Missão e pluralismo religioso
}

José Maria Vigil diz que o primeiro catecismo que se tem conhecimento na América Latina foi escrito por Pedro Córdoba, entre 1510 e 1521. Nesse catecismo, os nativos ficam conhecendo dois caminhos, do céu e do inferno. No céu estão todos que se converteram à fé cristã; no inferno estão “todos os que dentre vós morreram, todos os vossos antepassados: pais, mães, avós, parentes e quantos existiram e passaram por esta vida; e para lá ireis também vós, se não se fizerem amigos de Deus e não se batizarem e se tornarem cristãos". ${ }^{11}$ A missão promovida na América Latina, foi marcada por esse tom bélico e intransigente. É Vigil quem recolhe o relato de Máximo Flores, do Movimento Índio de Kollasuyo, quando da visita do Papa João Paulo II ao Peru em 1985:

\begin{abstract}
Nós, índios dos Andes e da América, decidimos aproveitar a visita de João Paulo II para devolver-lhe a sua Bíblia, porque em cinco séculos ela não nos deu nem amor, nem paz, nem justiça. Por favor, tome de novo sua Bíblia e devolva-a a nossos opressores, porque eles necessitam de seus preceitos morais mais do que nós. Porque desde a chegada de Cristóvão Colombo, impôs-se à América pela força uma cultura, uma língua, uma religião e valores próprios da Europa. A Bíblia chegou a nós como parte do projeto colonial imposto. Ela foi a arma ideológica desse assalto colonialista. A espada espanhola, que de dia atacava e assassinava o corpo dos índios, de noite se convertia na cruz que atava a alma índia. ${ }^{12}$
\end{abstract}

10 PUI-LAN, Kwok. Globalização, gênero e construção da paz: o futuro do diálogo interfé. São Paulo: Paulus, 2015. p. 21.

11 VIGIL, José M. Teologia do pluralismo religioso: para uma releitura pluralista do cristianismo. São Paulo: Paulus, 2006. p. 44.

12 VIGIL, 2006, p. 46. 
Tanto a missão de católicos quanto a de protestantes, em períodos diferentes, produziu o mesmo sentimento externado por Máximo Flores, ou seja, a constatação de que a Bíblia foi usada para legitimar a dominação, a violência e a exploração econômica. Mesmo assim, com essa herança histórica de subalternidade e movimentos autóctones de resistência ao modelo missiológico perpetrado por alguns séculos, ainda é possível perceber correntes missiológicas que têm no seu discurso um tom colonizador e na sua prática, uma ênfase doutrinária, dois elementos quanto à maneira de fazer missão. Por essa razão, há questionamentos de diferentes ordens. Um desses questionamentos se dá com a necessidade, ou não, de haver projetos missionários quando há um reconhecimento da cultura e religião do outro, e ainda mais quando se entende que o etnocentrismo deixou marcas indeléveis na trajetória política da América Latina, sentindo, em menor grau por alguns países, mais ainda perceptível em muitos, as dificuldades emancipatórias em termos econômicos e políticos.

Diante do quadro, ainda seria possível haver missão quando se reconhece o pluralismo religioso como um fato e, portanto, as religiões, naturalmente, tendo seus meios e códigos que correspondem a fé de uma gente? É mesmo plausível reivindicar a revelação do Deus de Israel que foi ocidentalizado a uma gente que entende haver uma plena conexão entre a vida e a natureza, como é o caso da população indígena, por exemplo? Quais os projetos missionários levariam em consideração a herança teológica de uma gente que, mesmo vilipendiada, preservou suas tradições e raízes na ancestralidade do seu povo? Uma outra questão, se dá no aspecto ético. O que ocorreria com projetos missionários quando diante do infanticídio praticado por motivação religiosa? Qual seria a postura diante de violações da dignidade humana em nome da crença religiosa? São questões difíceis de equacionar.

Admitir o pluralismo religioso e, concomitantemente, a tarefa missionária, tornase em árdua equação para teólogos pluralistas. Elencaremos alguns e suas respectivas ênfases quanto a relação pluralismo religioso e missão (a tarefa missionária).

José Maria Vigil insiste que não houve uma "clara distinção entre verdade salvadora e roupagem cultural judaico-cristã ocidental em que esta verdade se expressa". ${ }^{13}$ Propagar a vontade salvífica de Deus é, portanto, anunciar uma determinada cultura, povo e língua. Por essa razão, Vigil é enfático: “a convicção de que Deus quer que todos os humanos cheguem ao conhecimento da verdade (nossa!) foi uma arma sumamente perigosa nas mãos do Ocidente nesses vintes séculos de história". ${ }^{14}$ Por meio da força bélica, e com a ajuda tecnológica da época e a convicção teológica de que "do Senhor é a terra e tudo que nela há", produziu-se genocídio e pilhou-se riquezas de povos conquistados. Com isso, é possível entender que esse processo foi gestado por equívocos teológicos, principalmente quanto a figura de Jesus de Nazaré, interpretado como mandatário a partir de motivações

13 VIGIL, 2006, p. 402.

14 VIGIL, 2006, p. 402.

Protestantismo em Revista | São Leopoldo | v. 44, n. 01 | p. 266-291| jan./jun. 2018

Disponível em: <http:// periodicos.est.edu.br/index.php/nepp> 
questionáveis. ${ }^{15}$ Admitir o pluralismo religioso não apenas como um fato, mas como um direito, implica em repensar a missão. Para Vigil, um primeiro passo importante é não encarar "o lugar do destinatário como um 'vazio soteriológico', um lugar abandonado pela mão de Deus, um povo marginalizado do carinho de Deus". ${ }^{16}$ Quando o projeto missionário não se torna em agente de conversão, ou seja, quando o principal objetivo da missão não é a conversão do outro ao cristianismo, a perspectiva da missão precisa ser alocada em outra plataforma. Para Vigil, a missão, dentro de uma teologia missionária que tenha como base o pluralismo religioso, não pretende converter o outro, antes "os conteúdos sejam colocados de tal forma que a conversão seja sempre exceção, e que, em todo caso, seja possível a conversão em qualquer das direções. Que como norma, não espere mais conversões ao cristianismo do que aquelas possíveis também no sentido contrário" ${ }^{17}$ Nesse sentido, para alguns, a missão não teria propósito algum. Seria uma conversa de bons amigos sem a pretensão de converter o outro a verdade absoluta. Vigil não formula um programa missionário dentro das suas perspectivas quanto ao caráter da missão. Apenas certifica-se de que o modelo missionário foi alterado com o advento do paradigma pluralista. Assim, está aberto o futuro da missão, uma vez que "o futuro já não é a missão clássica, a conquista espiritual ou domínio do mundo por parte de uma instituição eclesiástica, a submissão de todas as almas a Cristo ou o triunfo da religião cristã sobre todas as religiões da terra". ${ }^{18}$

Paul Knitter também se preocupa com a missão a partir do paradigma pluralista. Como católico, assim como Vigil, há uma preocupação com os documentos da Igreja e as orientações do Magistério. Teólogos católicos que lidam com o pluralismo religioso, precisam fazer um excessivo esforço para conjugar problemas prementes no campo teológico e a demanda plural com o direcionamento oficial da Igreja. No tema missão, isso é algo notório. Knitter recorre aos documentos ${ }^{19}$ da Igreja, para dizer que há a possibilidade, nas entrelinhas, de que "os missionários devem não só proclamar e ensinar, mas também ouvir e aprender".20 Para Knitter, o desafio é dialogar enquanto se faz missão, em outras palavras, a missão é o diálogo. ${ }^{21}$ Sendo a missão, a partir do paradigma pluralista, uma condição para o diálogo, ou seja, a missão não se dá mais em pretensões de superioridade 22 do cristianismo em relação às demais religiões, Knitter pergunta: “Mas, se

15 VIGIL, 2006, p. 404.

16 VIGIL, 2006, p. 411.

17 VIGIL, 2006, p. 412.

18 VIGIL, 2006, p. 417.

19 Os principais documentos da Igreja que tratam do tema são: Redemptoris Missio de 1990 (RM) e Diálogo e Anúncio de 1991 (DA). Além do Concílio Vaticano II (1962-1965) e seus avanços no Diálogo Interreligioso. Para uma análise de ambos os documentos: TEIXEIRA, Faustino. Teologia das religiões: uma visão panorâmica. São Paulo: Paulinas, 1995. p. 138-179; DUPUIS, Jacques. Rumo a uma teologia cristã do pluralismo religioso. São Paulo: Paulinas, 1999. p. 489-509.

20 KNITTER, Paul. “A transformação da missão no paradigma pluralista", Concilium, n. 319, 2007/1, p. 102.

21 KNITTER, 2007, p. 103.

22 KNITTER, 2007, p. 104. 
a finalidade última do trabalho missionário, de acordo com o paradigma pluralista, já não é mais estabelecer a Igreja cristã como revelação e religião superior e definitiva sobre todas as outras, qual é então esta finalidade?". ${ }^{23}$ É uma boa pergunta, principalmente quando se está tratando com um ramo do cristianismo que participou ativamente de projetos de conquista com o lema da fé. A resposta que Knitter dá a essa pergunta é dupla. Para ele, a missão tem um caráter ad extra e ad intra. No primeiro aspecto, há a dimensão reinocêntrica. Fazer missão é fazer valer os valores do Reino de Deus. Nesse sentido, o projeto missionário é o mesmo de Jesus de Nazaré, ou seja, “o fim que proporciona o foco e a norma para todo o trabalho missionário é o mesmo fim que era o foco e a norma da missão e do ministério de Jesus: a Basileia tou Theou". ${ }^{24}$ Quando há pessoas de diferentes religiões imbuídas do mesmo projeto de Jesus de Nazaré, o Reino de Deus, há diálogo no entender de Knitter. Para ele, “a finalidade primária da missão-como-diálogo cristã: empenhar outras religiões, e qualquer pessoa que estiver interessada, no tipo de diálogo que promova aquilo que os cristãos simbolizam como a Basileia". ${ }^{25} \mathrm{Em}$ outras palavras, o diálogo só é possível quando todos estão envolvidos na missão de levar adiante o Reino de Deus, uma noção cristã. Nesse sentido, no nosso entender, não há diálogo estritamente, mas sim missão com a chancela do diálogo, quando o real objetivo é a conversão do outro: “Desejamos que a informação se infiltre, convença e ilumine a mente e o coração do parceiro de diálogo. Desejamos que o parceiro veja e sinta e seja movido pela verdade que anima nossa vida. Num sentido amplo, mas também profundo, isto é conversão" . ${ }^{26}$ Trata-se de diálogo quando se pretende convencer o outro de que há uma verdade correta, enquanto a do outro é mera especulação? Para Knitter, fazer missão é sinônimo de conversão do outro, embora de livre vontade, de que o Reino de Deus é a expressão máxima da vontade de Deus e levar adiante os valores do Reino de Deus é missão, com a prerrogativa do diálogo.

Outro teólogo de tradição católica que se dedica a pensar a missão a partir do paradigma pluralista, é Faustino Teixeira. Tanto Knitter quanto Teixeira, partem dos documentos já mencionados (RM e DA). Esses documentos constituem a base, com certas ambiguidades, da relação pluralismo religioso e missão. Teixeira explora essas possibilidades na sua profícua produção dentro da temática “Teologia das Religiões". Quando está lidando com os referidos documentos da Igreja, o autor não os trata de maneira acrítica: "num tempo marcado pela dinâmica do pluralismo religioso e pelo desafio imprescindível do diálogo, determinados documentos emitidos pelo Magistério eclesiástico acabam provocando perplexidade ou dúvidas com respeito às reais intenções de abertura anunciadas pela Igreja Católica".27 Ainda com "perplexidade ou dúvidas",

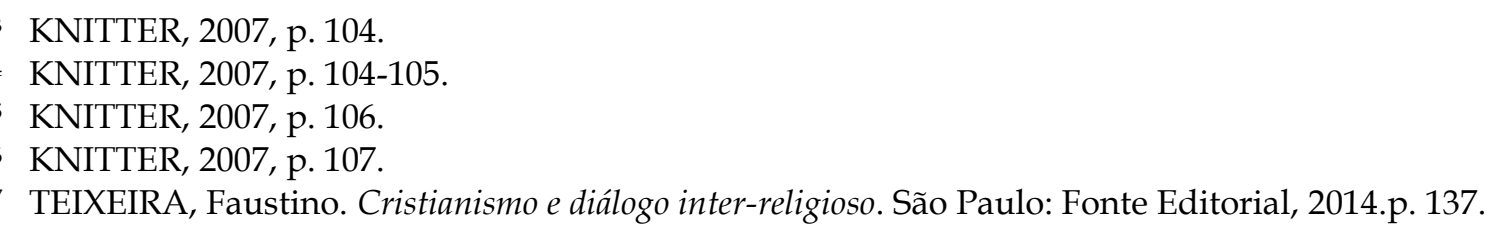


Teixeira trata o tema da missão a partir dos documentos - algo que os teólogos católicos não podem ignorar, mas interpretar. A perspectiva dos documentos, como vimos em Knitter, está na dimensão reinocêntrica, ou seja, o Reino de Deus como abertura e condição para se pensar a missão e o respectivo diálogo. Teixeira procura, de certa maneira, interpretar os documentos de modo positivo, mesmo admitindo problemas: "a história da salvação não se inicia com a chegada do agente evangelizador, como se entre os povos não evangelizados houvesse simplesmente uma 'ânsia' da verdade de Deus, depois respondida pelo entusiasmo do missionário". ${ }^{28}$ A missão se dá como testemunho em favor do Reino. ${ }^{29}$ Nesse sentido, “a missão evangelizadora da Igreja não consiste tanto em levar, necessariamente, à conversão e ao batismo, mas sobretudo ao testemunho vivo do Reino de Deus, que brilha para além de suas fronteiras". ${ }^{30}$ Mesmo com uma declaração como essa, Teixeira recorre ao documento Diálogo e Missão para enfatizar que o agente da conversão é o Espírito Santo sendo, portanto, "o cristão [um] simples instrumento e colaborador de Deus" 31 nesse processo. De qualquer modo, o diálogo se dá a partir da prerrogativa cristã, com seus códigos e categorias teológicas, ou seja, não é nada estranho não haver a disposição para o diálogo quando pautado pela reciprocidade teológica. Ocorre que, ao que parece, o Reino de Deus não é uma perspectiva ad intra para a Igreja perceber a emergência de uma postura dialógica em que os valores do Reino de Deus, expressos nos evangelhos, sejam a real inciativa para o diálogo com o outro, independentemente do pressuposto conversão. Tanto para Knitter quanto para Teixeira, a categoria Reino de Deus se dá na sua dimensão ad extra, ou seja, é algo que a Igreja leva para fora, portanto, o pressuposto para a tarefa missionária, em um contexto de pluralismo religioso, é o Reino de Deus, conceito que foi, até recentemente, identificado de diferentes maneiras, mas ainda pesa uma ideia de que Reino de Deus e Igreja são sinônimos, ou seja, ainda é frequente uma conotação de que esse aspecto teológico, Reino de Deus, abriga uma noção dominadora e legitimadora quanto aos avanços da Igreja no âmbito das religiões, mas, também, político. ${ }^{32}$ Assim, Reino de Deus não se constitui como um projeto em que a Igreja está em coparticipação com o proclamador do Reino, Jesus de Nazaré, mas, sim, como portadora dele, Reino de Deus, principalmente quando esse Reino é possível quando há conversão ao cristianismo. Em outro momento, Teixeira sinalizou algo assim quando tratou da figura de Jesus, a missão e o diálogo inter-religioso: "ganha aqui centralidade o estilo de vida de Jesus, o seu ideal, o sentido de sua existência, os valores que marcaram o seu projeto de vida voltado para o Reino de Deus". ${ }^{33}$ Uma vez essa concepção da figura de

\footnotetext{
28 TEIXEIRA, Faustino. Teologia das religiões: uma visão panorâmica. São Paulo: Paulinas, 1995. p. 225.

TEIXEIRA, 1995, p. 224.

TEIXEIRA, 1995, p. 226.

TEIXEIRA, 1995, p. 226.

2 Quem fornece um estudo desse aspecto é Jacques Dupuis, quando trata da "História recente das relações entre Igreja e Reino de Deus" - DUPUIS, Jacques. O cristianismo e as religiões: do desencontro ao encontro. São Paulo: Loyola, 2004. p. 249-253.

33 TEIXEIRA, 2014, p. 139.
} 
Jesus e sua relação com o Reino de Deus for viável, caberia a pergunta se a conversão, como entendida nos documentos da Igreja, dentro de um horizonte onde a missão se dá a partir do diálogo inter-religioso, seria ainda o objetivo? Se a Igreja é coparticipante e não portadora do Reino de Deus, a conversão teria ainda lugar? Teixeira parece ir nessa direção, embora não diga com todas as palavras: "é dando testemunho dos valores do Reino com o seu ser e agir que a Igreja traduz fidelidade ao seguimento de Jesus e consegue confirmar sua credibilidade no tempo atual". 34

Ainda dentro da percepção de teólogos católicos quanto ao tema pluralismo religioso e a missão, o nome de Claude Geffré merece destaque. Falecido em 2017, Geffré deixou suas marcas como um dos principais teólogos a pensar o diálogo inter-religioso e fincar algumas bases para uma Teologia das Religiões. Quando trata da relação missão e pluralismo religioso, Geffré é cauteloso com a sua tradição. No seu entender, “o diálogo já é uma forma essencial de missão". 35 Ele admite essa possibilidade por estar cônscio de que "a missão como proclamação e apelo à conversão, se tornou muito difícil, até mesmo impossível" . ${ }^{36}$ Ainda assim, Geffré não vê problema com a ideia de se fazer missão: "penso que a missão da Igreja não perdeu nada de sua urgência e que o diálogo inter-religioso, fundado num maior otimismo quanto às possibilidades de salvação fora da Igreja, em nada compromete o sentido mais tradicional da missão". ${ }^{37}$ E como se daria isso? Como teólogo católico, Geffré não poderia ignorar os documentos da Igreja que tratam do tema (RM e DA). É com base neles que o autor procura elaborar uma ideia de missão dentro do paradigma do pluralismo religioso. Aliás, para Geffré, "o pluralismo religioso permanece um destino histórico permitido por Deus, cujo significado está oculto aos nossos olhos" ${ }^{38}$ Com essa noção de pluralismo religioso, Geffré não fala em conversão, mas sim em diálogo de salvação, ou seja, há um "esforço, na fidelidade à sua própria verdade, para celebrar uma verdade que ultrapassa os limites e as incompatibilidades de cada tradição religiosa". ${ }^{39}$ Ao que parece, a preocupação de Geffré se dá na possibilidade concreta do diálogo. Para ele, não há diálogo quando o objetivo é proselitista. Quando em diálogo com outra tradição religiosa, o missionário também recebe algo. Dito de outro modo, o missionário "não está na situação de alguém que dá tudo a quem não tem nada. Ele também recebe, descobre de novo a sua identidade cristã quando é interpelado por outras religiões". ${ }^{40}$ Mesmo admitindo que a missão se dá no diálogo inter-religioso,41 Geffré não vê dificuldade alguma em dizer que, num primeiro momento da missão, não há necessidade de “fazer

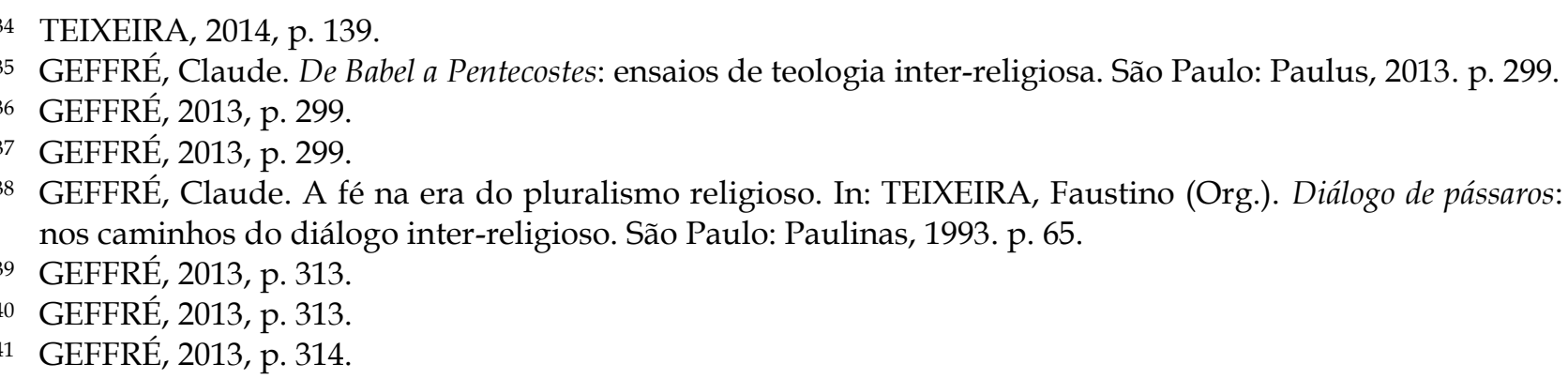


menção do acontecimento Jesus Cristo", 42 mas depois é preciso anunciar Jesus. Para Geffré, a abertura para o diálogo inter-religioso se dá em missão, mas uma vez em diálogo é necessário estabelecer as condições do cristianismo e sua dimensão cristocêntrica, tendo o Reino de Deus como fundamento. Mesmo assim, Geffré resume o real teor da missão que se dá no diálogo:

Pode-se, num primeiro tempo, anunciar o Reino de Deus e o apelo à conversão para nele entrar, sem ainda fazer menção do acontecimento Jesus Cristo. Mas, depois de ter manifestado, por palavras e atos, o Reino que vem, deve-se anunciar Jesus Cristo, que, na sua total humanidade, inaugurou o Reino de Deus e nos revelou a verdadeira face de Deus. Finalmente, deve-se levar a descobrir o mistério da Igreja como o lugar onde Deus vem ao encontro dos homens e como resultado final da busca da Realidade última já em processo no seio de outra religião. ${ }^{43}$

Parece que Geffré não pensa em nada diferente do que já foi colocado pela Igreja e seus documentos que tratam da missão e sua relação com o diálogo inter-religioso. Ainda que se afirme que o diálogo é uma forma de missão, Geffré não articula algo além dos documentos da Igreja, assim como os demais teólogos de tradição católica mencionados aqui. O que ele faz, e nos soa como algo articulado previamente, é entrar no diálogo com o objetivo de fazer missão e, quando estabelecido alguns caminhos para a conversação, deixar os principais dogmas da Igreja bem claros e as condições para a sua aceitação.

Aparentemente, os teólogos de tradição católica elencados até aqui, não parecem ter divergências quando tratam do pluralismo religioso e sua relação com a missão. Os documentos da Igreja sobre o tema se constituem como base para o fazer teológico, não havendo, ao que parece, nenhuma possibilidade de dissonância com a postura e orientação oficial da Igreja por parte dos intérpretes. Enquanto um procura atenuar a tarefa missionária, alegando de que o modelo de missão centrado na conversão não é mais possível a partir do paradigma do pluralismo religioso (Vigil); outro delineia as possibilidades para o diálogo, mas deixa claro que a conversão é algo desejável (Knitter); mesmo havendo a necessidade de se pautar a missão a partir da figura de Jesus de Nazaré (Teixeira), ainda é patente a ideia de que, no fim mesmo, as categorias teológicas da Igreja precisam prevalecer, uma vez que a Igreja ainda detém a primazia diante das religiões (Geffré). Haveria outras possibilidades para essa relação missão e pluralismo religioso? Havendo, como se daria isso? Ao nosso ver, teólogos de tradição protestante podem contribuir para essa equação por terem outra perspectiva, ou seja, uma perspectiva que difere dos teólogos católicos, que precisam olhar nos documentos da Igreja e interpretá-los para fechar alguns fios soltos. É nesse sentido que passamos a elencar algumas ideias dentro da tradição protestante, constatando, de início, que há poucos autores que tratam

42 GEFFRÉ, 2013, p. 314.

43 GEFFRÉ, 2013, p. 314. 
do tema, sendo um dos motivos (é a nossa hipótese), a natureza plural do protestantismo e suas diferentes ênfases. Os teólogos protestantes que procuram pensar a temática da Teologia das Religiões e seus temas correlatos, como pluralismo religioso, diálogo interreligioso e missão, operam em plataformas teológicas diferentes, a começar pelo lugar de onde está se falando.

A percepção que se tem da realidade missionária latino-americana é que, mesmo com algumas tentativas de "latinoamericanização" de algumas práticas das igrejas, “a compreensão de missão ainda é limitada ao projeto expansionista proselitista (construção de novas igrejas) e à pregação do abandono do catolicismo para adesão à fé protestante". ${ }^{44}$ Em termos gerais, as dificuldades que o universo católico tem com a missão quando lida a partir do pluralismo religioso não é muito diferente do universo protestante, que precisou buscar a sua legitimação diante do grupo majoritário (católico) fazendo deste um "inimigo a ser combatido". Com isso, houve uma "desconexão com o jeito de ser e de viver da população e um fechamento às demandas sociais e culturais" . ${ }^{45}$ Este cenário, favoreceu a diversidade de perspectivas em termos missionários, uma vez que a natureza protestante abriga uma pluralidade evidente por não ter, dentre outros fatores, um ponto fixo, embora tenham, praticamente, a mesma linguagem, mas ainda assim, polissêmica e dissonante. ${ }^{46}$ Com esse quadro plural, não é possível fixar um ponto comum aos protestantes, ou seja, a tradição protestante permite olhar diferentes perspectivas, focando, assim, em questões e ênfases (teológica, política, econômica e social) que para um determinado grupo é importante, mas para outro não é. Com isso, é possível haver grupos que nutrem uma leitura literalista da Bíblia e tornam o proselitismo a sua principal bandeira, levando adiante uma versão do evangelho mais fechado, fundamentalista e autoritário quando em missão. Por outro lado, há grupos que são considerados progressistas e nutrem uma leitura do evangelho primando pela liberdade, a justiça e os valores do Reino de Deus de maneira incisiva, fazendo da postura ecumênica a principal bandeira. Para esse grupo, por exemplo, a visão de que o cristianismo deveria ser expandido para grupos indígenas ou comunidades afro-latinas, é descartada. ${ }^{47}$ Antes, a leitura que se faz do cristianismo é de que ele "precisa ser vivido entre essas populações, que carecem de solidariedade, respeito e tolerância - e aqui o critério ético é a vida". ${ }^{48}$

O protestantismo precisou tratar a missão e sua relação com a pluralidade religiosa quando no seu movimento missionário. Foi exatamente no desenvolvimento missionário que o protestantismo encontrou o seu elemento embrionário para se pensar

\footnotetext{
44 RIBEIRO, Claudio; CUNHA, Magali. O rosto ecumênico de Deus: reflexões sobre ecumenismo e paz. São Paulo: Fonte Editorial, 2013. p. 190.

45 RIBEIRO; CUNHA, 2013, p. 190.

46 Um texto que procura dar conta da diversidade e ênfases dos missionários: CALDAS, Carlos. O último missionário. São Paulo: Mundo Cristão, 2001.

47 RIBEIRO; CUNHA, 2013, p. 197.

48 RIBEIRO; CUNHA, 2013, p. 197.
} 
em uma Teologia das Religiões. Magali Cunha, pesquisadora do tema e integrante do Conselho Mundial de Igrejas (CMI), assegura que foi o "movimento missionário [um] elemento motivador para a inserção do pluralismo na agenda protestante". ${ }^{49}$ Quando o movimento missionário de linha liberal no século XIX entrou em contato com outras expressões religiosas, "despertou um primeiro interesse protestante pelo conhecimento mais objetivo e profundo das religiões". ${ }^{50}$ Assim como na América Latina o divisionismo protestante gerou movimentos de unidade, promovendo o ecumenismo, na Europa "a consciência do escândalo da divisão e a necessidade de cooperação e unidade no trabalho evangelístico representou a gênese do que hoje conhecemos como movimento ecumênico". ${ }^{51}$ Ocorre que lá, o movimento ecumênico não focou (ou ficou) apenas na unidade entre as igrejas. Com a Conferência de Edimburgo (1910), “abriu caminho para a realização de outras [conferências] que construíram uma teologia da missão e caminhos de unidade no trabalho missionário. E com isso construiu-se também uma reflexão sobre culturas e religiões". 52 As conferências missionárias que se seguiram à de Edimburgo tinham como pauta, dentre outros temas, "a mensagem missionária em relação as religiões não-cristãs". ${ }^{33}$ Nesse processo, o CMI desenvolveu um importante papel. Como bem observa Christine Lienemann-Perrin, ${ }^{54}$ com o CMI há um esforço em buscar dialogar com outras expressões religiosas e, para isso, o Conselho trabalhou com, pelo menos, quatro facetas: (1) a disposição de se expor ao estranho; (2) dar nova expressão à fé (cristã) a partir do encontro; (3) formar uma comunhão de vida e de serviço com pessoas de outras religiões, abrindo-se para o testemunho recíproco; (4) atentar para a sempre necessária diferenciação. Com a Conferência de Edimburgo e o trabalho do CMI, há uma abertura para se pensar o diálogo inter-religioso a partir da tarefa missionária. ${ }^{55}$

\section{Diálogo e missão}

A tarefa missionária constitui-se inerente à natureza do cristianismo, ou seja, a missão está na vocação do cristianismo e dela, a missão, o cristianismo não pode abrir mão, sendo algo intrínseco à sua identidade. Naturalmente que essa assertiva traz implicações e ambiguidades. As versões católica e protestante do cristianismo estão diretamente ligadas ao movimento missionário em diversos lugares do mundo. $\mathrm{Na}$

49 CUNHA, Magali. Pluralismo religioso na agenda das igrejas protestantes no mundo contemporâneo. In: BHOGAL, Inderjit S. Pluralismo religioso e a missão da igreja na atualidade. São Bernardo do Campo: EDITEO, 2007. p. 26.

50 CUNHA, 2007, p. 26.

51 CUNHA, 2007, p. 28.

52 CUNHA, 2007, p. 28.

53 CUNHA, 2007, p. 29.

54 LIENEMANN-PERRIN, Christine. Missão e diálogo inter-religioso. São Leopoldo: Sinodal, 2005. p. 86.

55 Há uma síntese dos principais autores protestantes (Wesley Ariarajah, Christine Lienemann-Perrin e Inderjit S. Bhogal) que desenvolveram o tema da missão a partir do diálogo inter-religioso em: RIBEIRO, Claudio; SOUZA, Daniel. A teologia das religiões em foco: um guia para visionários. São Paulo: Paulinas, 2012. p. 134-161. 
América Latina, conhecemos como esse processo se deu quando os agentes eram católicos e protestantes. ${ }^{56}$ Processo esse que deixou marcas na história latino-americana e, como atestam pesquisadores, não se deu de maneira salutar.

Agora, a discussão quanto à missão passa pelo aspecto positivo da cultura, no sentido de levar em consideração a complexidade cultural e suas ramificações, inclusive religiosa. Assim, a pergunta que se faz quanto à (in)viabilidade da missão, está permeada pelo paradigma do pluralismo religioso e, consequentemente, a possibilidade do diálogo inter-religioso. Ainda é possível falar em missão quando se admite que, assim como o cristianismo, as demais religiões têm seus códigos de acesso ao sagrado? A resposta a essa pergunta precisa levar em consideração alguns elementos, quais sejam: "religiões são caminhos ordinários de salvação dos seus respectivos povos. Culturas e religiões têm uma normatividade interna. Nenhuma dessas culturas e religiões, porém, é, por princípio, normativa para outras culturas e religiões". ${ }^{57}$ Uma vez admitindo isso, surgem algumas propostas para essa possível interação do cristianismo - culturalmente determinado, ou seja, códigos de acesso ao sagrado mediados pelo contexto judaico e helênico, e ocidentalizados com suas diferentes interpretações - com as demais culturas e suas respectivas religiões. Nesse caso, parece ser possível falar em inculturação. ${ }^{58} \mathrm{Um}$ tema complexo e com diferentes perspectivas. ${ }^{59}$ Há quem trate do tema de outra maneira, falando em interculturalidade, ou seja, uma "perspectiva da interculturalidade habilita o cristianismo para a pluralidade das culturas e das religiões, que o habilita para o exercício plural de sua própria memória". 60 Aqui ocorre um movimento de "mão dupla", quando se "quebra o isolamento produzido por uma preocupação excessiva com questões locais e setoriais". ${ }^{61}$ Isso significa, olhar para além das questões menores (locais e setoriais) que apequenam projetos maiores, aqueles que envolvem maior integração e reflexão, exigindo, portanto, sinergia e comprometimento dos envolvidos. É nesse sentido que falamos de diálogo e missão e a busca por pontos comuns.

56 Para uma explanação detalhada da tarefa missionária protestante na América Latina: PIEDRA, Arturo. Evangelização protestante na América Latina: análises das razões que justificaram e promoveram a expansão protestante (1830-1960). São Leopoldo: Sinodal, 2006. v. 1.

57 SUESS, Paulo. Pluralismo e missão: por uma hermenêutica da alteridade. In: VIGIL, José Maria et al. (Orgs.). Teologia pluralista libertadora intercontinental. São Paulo: Paulinas, 2008. p. 95.

58 "Inculturação significa o movimento que assume as culturas locais e seus valores como o instrumento básico e um poderoso meio de apresentar, reformular e viver o cristianismo. Dentro desse processo ocorre o diálogo efetivo entre o cristianismo e as culturas locais". WALIGGO, John. Inculturação. In: LOSSKY, Nicholas et al. (Eds.). Dicionário do movimento ecumênico. Petrópolis: Vozes, 2005. p. 651.

59 Aqui estamos pensando em dois textos: MIRANDA, Mario de França. Inculturação da fé: uma abordagem teológica. São Paulo: Loyola, 2001; TEIXEIRA, Faustino. Inculturação da fé e pluralismo religioso. In: TAVARES, Sinivaldo S. (Org.). Inculturação da fé. Petrópolis: Vozes, 2001. p. 82-94.

60 FORNET-BETANCOURT, Raúl. Religião e interculturalidade. São Leopoldo: Sinodal, 2007. p. 53.

61 RIBEIRO; CUNHA, 2013, p. 194. 
Quando David J. Bosch aborda o tema "Diálogo e missão", 62 ele admite tratar de "um mistério". Entende que a relação entre diálogo e missão, deveria ser "um encontro de corações e não de mentes". Para esse encontro ser possível, Bosch destaca algumas perspectivas que serviriam de balizas: 1) Aceitar a coexistência de crenças diferentes e fazê-lo de boa vontade, sem relutância; 2) Um diálogo autêntico com compromisso; 3) O diálogo só é viável se procedermos com a crença de que não estamos avançando para um vácuo; 4) Diálogo e missão só podem se concretizar em uma atitude de humildade; 5) Tanto o diálogo quanto a missão deveriam reconhecer que as religiões são mundos em si, com seus próprios eixos e estruturas. Essas considerações de Bosch, quanto à relação entre diálogo e missão na contemporaneidade, refletem a perspectiva protestante acumulada por algumas décadas entre conferências, reflexões e práxis missionária. Destacamos aqui a terceira e a quinta perspectiva, por entender que ambas contribuem para o que pretendemos, ou seja, a tentativa em articular uma concepção de missão que tem no diálogo, per si, o seu principal elemento. Entendemos que o diálogo só é plausível quando há um ponto (ou mais) em questão, do contrário está se "avançando para um vácuo". Sendo as religiões "mundos em si, com seus próprios eixos e estruturas", pretendemos fazer uma aproximação entre missão e diálogo sem a mediação do conceito de inculturação. 63 Mesmo havendo genuína intensão de aproximação (inculturação) com o pressuposto do respeito, do diálogo e da alteridade, ainda há uma postura teológica e, em algum sentido, arrogante quando parte-se do ponto de que a cultura do outro se constitui como "alvo" da manifestação de Deus. ${ }^{64}$ A postura missionária que advoga a primazia da manifestação do sagrado na sua tradição de fé num primeiro momento, não abriga a dimensão do diálogo de maneira genuína, mesmo que ele esteja sendo colocado. Católicos, com os seus documentos oficiais e suas insígnias antecipatórias, e protestantes, com sua retórica colonialista e pureza doutrinária, não nutrem condições de propor um comportamento missionária a partir de outras bases como o diálogo em si. Bosch, demonstra sinceridade (proclamação da fé cristã) e coerência (o diálogo e a missão), sintetizando a postura do missionário quando diante do outro: "cremos que a fé que professamos é tanto verdadeira quanto justa e deve ser proclamada. Não o fazemos,

62 BOSCH, David J. Missão transformadora: mudanças de paradigma na teologia da missão. 3.ed. São Leopoldo: Sinodal, 2009. p. 576-584.

63 Estamos cientes dos modelos de "inculturação" apresentados por ZWETSCH, Roberto. Inculturação. In: BORTOLLETO FILHO, Fernando (Ed.). Dicionário brasileiro de teologia. São Paulo: ASTE, 2008. p. 526-527. Um texto que abre esse debate a partir de categorias como a "secularização": AZEVEDO, Marcello de Carvalho. Modernidade e cristianismo: o desafio à inculturação. São Paulo: Loyola, 1981.

64 "Inculturar, no sentido teológico, vai além da adaptação antropológica e do respeito ao outro. Permite que cada cultura exprima Deus e sua mensagem a partir dos modos de ser, pensar e de se manifestar próprios. Nesse processo, a cultura é aperfeiçoada e a apropriação do evangelho enriquecida com novas reflexões e contribuições de cada cultura". OLIVEIRA, David M. Diálogo e missão nos Andes: um estudo de teologia da missão latino-americana. São Paulo: Reflexão, 2017. p. 160. 
todavia, como juízes ou advogados, mas como testemunhas; não como soldados, mas como mensageiros da paz". 65

\section{As bases para o diálogo: Paulo Freire e Kwok Pui-Lan}

Quais seriam as bases para o diálogo inter-religioso? É possível haver diálogo quando as partes não têm pontos, ainda que divergentes, comuns? Como iniciar uma conversa se não há códigos, ainda que distintos, que sejam, minimamente, compartilhados? Uma vez tendo o diálogo como elemento básico da missão, é preciso dizer quais seriam as condições para esse diálogo e, como consequência, a missão. Não havendo o mínimo de interesse comum em algo colocado, seria possível haver uma plataforma de interação e, até mesmo, convergências? É nesse sentido que colocamos as reflexões de Paulo Freire, educador brasileiro, como uma possibilidade em pensar o escopo da missão. Ainda que o nosso esforço seja, também, teológico, esse aspecto (teológico), não se constitui como algo impermeável. Isso ficará ainda mais evidente quando elencarmos a contribuição de Kwok Pui-Lan para o diálogo inter-religioso.

Quando Paulo Freire coloca as bases para o diálogo, a principal se dá com algo fundamental para a vida, o amor: "não há diálogo, porém, se não há um profundo amor ao mundo e aos homens". ${ }^{66}$ Mesmo que esse seja um elemento de condições subjetivas, ele é demonstrado, ou seja, o "fundamento do diálogo, o amor é, também, diálogo". ${ }^{67}$ Esse fundamento para o diálogo se dá de maneira intensa e aberta, porque "se não amo o mundo, se não amo a vida, se não amo os homens, não me é possível o diálogo". 68 O amor não se dá em condições abjetas. Ele promove a ação, o agir. Noêmia Santos, quando estuda o pensamento de Paulo Freire, ressalta que para o educador o amor se dá na disposição para o outro e essa disposição estabelece uma base comum para o diálogo: "ao amar, acolhemos com mais disposição o que a pessoa amada sugere, embora seja diferente do que pensamos. Este sentimento dá condições para as pessoas superarem os conflitos gerados no momento do diálogo" ${ }^{69} \mathrm{O}$ diálogo, tendo no amor um dos seus fundamentos, permite uma postura diante do mundo. O conceito de mundo para Freire, ou a pronúncia do mundo, é o ato de recriar, ou seja, se dá na superação de uma "antiga situação criando uma nova". ${ }^{70}$ Quando o diálogo seria possível? Quando há amor. O que esse amor leva? Para Freire, leva a uma práxis no mundo. Quando as partes do diálogo agem com autossuficiência, não há diálogo; quando uma das partes vê ignorância apenas no outro e não em si mesmo, não há diálogo; quando uma das partes não têm humildade para sentar

\footnotetext{
BOSCH, 2009, p. 584.

66 FREIRE, Paulo. Pedagogia do oprimido. 50.ed. Rio de Janeiro: Paz e Terra, 2011. p. 110.

67 FREIRE, 2011, p. 110.

68 FREIRE, 2011, p. 111.

69 SANTOS, Noêmia. Por uma educação libertadora: pedagogia dialógica a partir de Paulo Freire e Juan Luis Segundo. São Paulo: Fonte Editorial, 2012. p. 53.

70 SANTOS, 2012, p. 53.
} 
com o outro, não há diálogo. No diálogo, não pode haver um tom arrogante; no diálogo não pode haver uma prerrogativa de conhecimento absoluto; no diálogo não pode haver a ligeira pretensão de absolutizar uma única linguagem. Diz Freire: "ao fundar-se no amor, na humildade, na fé nos homens, o diálogo se faz uma relação horizontal". ${ }^{71}$ Além do amor, uma base fundamental para o diálogo, Freire coloca uma outra também, a esperança. "Não existe, tampouco, diálogo sem esperança". ${ }^{72}$ Mas essa esperança não se dá no imobilismo, na inércia, antes, a esperança é a condição da práxis: "movo-me na esperança enquanto luto e, se luto com esperança, espero". ${ }^{73}$ Essas duas bases, uma vez ligadas, amor e esperança, fundamentam o diálogo para Freire. Agora resta saber qual a motivação para o diálogo. Uma vez colocadas as condições e as inibições para o diálogo, Freire é taxativo: "se os sujeitos do diálogo nada esperam do seu quefazer, já não pode haver diálogo". ${ }^{74}$ Só pode haver diálogo quando sujeitos estão dispostos a dialogar sobre algo em comum, ou seja, só pode haver diálogo quando sujeitos nutrem uma inquietação em comum, ainda que sejam em diferentes aspectos..$^{75}$ Se não há uma motivação comum para os dialogantes, não será possível haver um diálogo. O diálogo, pressupõe uma práxis em conjunto, uma postura crítica diante de uma situação que carece de transformação. Se não há essa postura, não há diálogo, mas sim antidiálogo, ${ }^{76}$ ou seja, uma tentativa de dominação de um sobre o outro. Com isso, Freire contribui para o que propomos aqui, porque oferece bases para o diálogo (amor e esperança), mas também elemento para que esse diálogo aconteça (a práxis diante de algo que precisa ser recriado).

A teóloga Kwok Pui-Lan vem acumulando uma profícua produção teológica, dedicando-se a pensar a relação entre pluralismo religioso, diálogo inter-religioso, globalização e gênero, dentre outros temas emergentes. No texto já citado da autora, Globalização, gênero e construção da paz, Pui-Lan sintetiza questões que estão na pauta do pluralismo religioso, do diálogo inter-religioso, da busca pela paz e gênero. Ainda que seja um texto pequeno (um opúsculo), o texto representa uma busca por algo que estava faltando no debate em torno da Teologia das Religiões e seus temas correlatos. Pui-Lan coloca a temática do diálogo inter-religioso em estreita relação com os principais temas contemporâneos. A missão está contemplada na sua reflexão e sua conexão com o diálogo inter-religioso, aspecto que pretendemos abordar.

Em certo sentido, entendemos que a reflexão de Pui-Lan agrega a noção de diálogo em Freire quando se pensa em missão. Se para o educador brasileiro o diálogo só é possível quando se tem um (ou mais) ponto em comum, Pui-Lan entende que o diálogo não precisa, necessariamente, embora ele seja importante enquanto cúpula institucional,

\footnotetext{
FREIRE, 2011, p. 113.

FREIRE, 2011, p. 113.

FREIRE, 2011, p. 114.

FREIRE, 2011, p. 114.

FREIRE, 2011, p. 115-116.

SANTOS, 2012, p. 56.
} 
ser mediado por religiões, mas antes por pessoas com suas crenças e tradições. ${ }^{77}$ Mesmo considerando as contribuições feitas pelo Concílio Vaticano II (1962-1965), como também as conferências promovidas pelo protestantismo e o CMI para o tema do diálogo interreligioso e sua relação com a tarefa missionária, a autora entende que o diálogo se dá entre pessoas de fé (interfé), e não necessita ter, precisamente, a tutela de uma religião no seu sentido institucional: “o diálogo é o encontro entre pessoas de fé viva e não entre o cristianismo e outras religiões. Cada um fala como uma pessoa de fé, a partir de profundo e firme compromisso com sua fé e tradição". ${ }^{78} \mathrm{O}$ diálogo interfé não se pretende fazer proselitismo, muito menos converter pessoas ao cristianismo alegando de que ele, o cristianismo, é superior às outras religiões,79 antes, "o diálogo ajuda a identificar as preocupações comuns e promove a construção de uma humanidade mais ampla". ${ }^{80}$ Aqui, é possível, ao que parece, colocar na mesma mesa Freire e Pui-Lan. O diálogo só é possível, com os seus devidos fundamentos (amor e esperança) explicitados por Freire, quando há uma clara percepção de que algo precisa ser feito (práxis) e, para isso, há um ponto em comum que, embora seja diferente na sua concepção, torna possível o início da conversa. "O diálogo de ação acontece quando pessoas e organizações religiosas de diversas tradições de crenças colaboram e juntam esforços para tratar de problemas comuns de uma comunidade local ou de preocupações mais amplas". ${ }^{81}$ Qual o sentido do diálogo quando não há um mínimo de consenso quanto ao principal ponto a dialogar? Havendo um consenso quanto ao principal ponto a dialogar, o que se pretende fazer (práxis) diante de uma situação que espera uma nova pronúncia (Freire)?

Para Pui-Lan, o diálogo pode acontecer a partir de experiências espirituais. Essa esfera do diálogo não há tanta dificuldade. ${ }^{82} \mathrm{O}$ que realmente se torna um complicador, é o diálogo em torno de crenças, dogmas e teologias. Essa esfera seria possível? Para PuiLan, essa esfera de diálogo tem sérias dificuldades, uma vez que as "tradições diferentes têm suas reivindicações normativas, enquanto doutrinas religiosas e dogmas estão entretecidos em molduras culturais específicas e em mundividências religiosas". ${ }^{83}$ Mesmo que essa esfera do diálogo seja possível, o que, ao nosso ver não seria por razões doutrinárias, qual seria o seu quefazer? Dialogar em torno de doutrinas e posicionamentos dogmáticos das respectivas religiões parece não ter muito sentido. Tendo as religiões seus códigos de acesso ao sagrado com particularidades, o diálogo se daria em torno de pretensões absolutistas quanto ao dogma professado. Além disso, a concepção quanto à missão estaria, novamente, imbuída de autoritarismo cultural. O que Pui-Lan argumenta, é que há um tema premente que precisa ser mediado por meio do diálogo, a construção da

\footnotetext{
PUI-LAN, 2015, p. 21.

78 PUI-LAN, 2015, p. 25.

79 PUI-LAN, 2015, p. 25.

30 PUI-LAN, 2015, p. 25.

81 PUI-LAN, 2015, p. 26.

32 PUI-LAN, 2015, p. 26.

33 PUI-LAN, 2015, p. 26.
} 
paz: "o diálogo interfé deve ser uma força para a construção da paz". ${ }^{84}$ Antes do debate teológico ou doutrinário, há temas que precisam, com urgência, de atenção. A paz, inevitavelmente, é um desses temas. A construção da paz, como bem lembra Hans Küng, passa pelas religiões, uma vez que, na sua quase totalidade, as religiões buscam meios para a paz, com exceções de extremismos e interpretações fundamentalistas. Aqui, dialoga-se para que haja uma busca de meios que favoreçam a paz. Isso é possível quando há um ponto em comum para o diálogo, havendo esse ponto, há uma missão (práxis), mas antes de um quefazer, a missão é dialogar no sentido de encontrar outros pontos comuns. Um termo que Pui-Lan entende ser adequado para pensar em um diálogo em torno de temas comuns é a polidoxia. Com esse termo, a teóloga destaca que "os cristãos não têm monopólio da revelação de Deus, e que a divindade deveria ser compreendida em termos de multiplicidade" .85 Partindo da ideia de polidoxia enquanto patrimônio da verdade e manifestação de "deus", abre-se "mais espaço para o diálogo, visto que alivia a pressão de ter de defender a própria identidade singular, uma vez que as fronteiras do eu e da própria tradição estão em constante mudança" .86

Assim, entendemos que a contribuição de Freire e Pui-Lan ajudam no processo de fundamentar o diálogo inter-religioso. Enquanto Freire coloca os alvos e as condições que o fundamentam para um possível diálogo, Pui-Lan contribui com uma leitura teológica que abdica da pretensão de ser absoluta no discurso sobre Deus (polidoxia). Com isso, a proposta da missão se dá no diálogo, primeiramente, uma vez nele (no diálogo), só é possível quando há um ou mais temas que lhe seja comum.

\section{As bases para a missão: Jürgen Moltmann}

Seguimos David J. Bosch quando este faz a distinção entre missão (no singular) e missões (no plural). Como sinalizamos, o nosso foco está no primeiro termo. Missão (missio Dei) se dá com "o envolvimento de Deus no e com o mundo, a natureza e atividade de Deus, que compreende tanto a igreja quanto o mundo, e das quais a igreja tem o privilégio de participar". ${ }^{87}$ Quando Bosch ressalta o "privilégio de participar", está deixando claro que não cabe à Igreja a tutela da missão, antes, a Igreja "é um sinal no sentido de indicação, símbolo, exemplo ou modelo". 88 Missão como o "envolvimento de Deus no e com o mundo", entende-se que não há fronteiras fixas para tal atividade, sendo assim, a missio Dei não está circunscrita à política, geografia ou denominação específica.

A missão se dá no "envolvimento". Para que isso seja possível, entendemos que o diálogo é o alvo da missão, uma vez que este (o diálogo), leva ao envolvimento entres

84 PUI-LAN, 2015, p. 32.

85 PUI-LAN, 2015, p. 74.

86 PUI-LAN, 2015, p. 81.

87 BOSCH, 2009, p. 28.

88 BOSCH, 2009, p. 29. 
sujeitos de fé ou/e instituições religiosas. Ao nosso ver, quem melhor articula essa concepção de missão é o teólogo alemão de destaque na América Latina, Jürgen Moltmann. Para ele, a missão se dá em relações abertas, ou seja, missão não é expandir o “império cristão, a civilização cristã ou os valores religiosos ocidentais". ${ }^{89}$ Quando a tarefa missionária da Igreja esteve atrelada ao expansionismo, o cristianismo ficou marcado por cisões e conflitos. A lógica que Moltmann propõe é outra. Para ele, a missão é “o convite ao futuro de Deus e à esperança pela nova criação de todas as coisas". 90 Ele aposta de que uma vez seguindo essa concepção de missão, ou seja, "quando a paixão pelo futuro de Deus tomar o lugar da expansão da Igreja", não haverá mais razões para cismas e expansionismo denominacional, uma vez que a premissa será “a esperança do Reino de Deus". ${ }^{91}$ É bom dizer que a categoria teológica Reino de Deus em Moltmann não se dá de maneira ad extra, como nos documentos oficiais da Igreja Católica, quando o Reino de Deus é algo que se faz para fora, ou seja, é preciso colocá-lo em evidência na sociedade por meio do conteúdo doutrinário da Igreja, e isso se faz por meio do diálogo inter-religioso. A concepção de Reino de Deus em Moltmann se dá de maneira ad intra: “a Igreja deve refletir e representar o Reino de Cristo em primeiro lugar dentro de si mesma". ${ }^{92}$ A Igreja precisa vivenciar os valores do Reino dentro dela mesma. E como ela faz isso? Quando ela coloca em prática os valores do Reino de Deus, sendo a manifestação desses valores, primeiramente, para os seus membros. Dessa forma, uma Igreja que vivência os valores do Reino de Deus, não permite posturas racistas e discriminatórias; não abriga dentro de si a distinção de classes; não promove um comportamento patriarcal, onde apenas os homens dominam; não coaduna com qualquer tipo de nacionalismo; em uma Igreja que promove os valores do Reino de Deus, não há espaço para privilégios de natureza religiosa, política, econômica ou sexual. Antes, uma Igreja que olha para o Reino de Deus acolhe o outro como pessoa, nas suas debilidades e qualidades. ${ }^{93}$ Sendo assim, essa Igreja está apta para fazer missão, a partir da sua percepção quanto à natureza do Reino de Deus.

Essa noção de Reino de Deus implica em superar a ideia de que missão se faz com o envio de missionários como se eles, somente, fossem os responsáveis pela tarefa missionária. No entender de Moltmann isso é um equívoco. Além disso, essa concepção de missão, como envio de alguns para determinados lugares com o propósito de evangelizar, encontra resistência em diferentes aspectos, não apenas o teológico, como também nos estudos culturais. É preciso ir além. Para o autor, missão é participação nos sofrimentos do povo e, principalmente, no fomentar a esperança. Essa característica de missão se dá no comprometimento e na solidariedade. A missão nunca é um fim em si mesma, antes é a

89 MOLTMANN, Jürgen. A fonte da vida: o Espírito Santo e a teologia da vida. São Paulo: Loyola, 2002. p. 28.

90 MOLTMANN, 2002, p. 29.

91 MOLTMANN, 2002, p. 29.

92 MOLTMANN, Jürgen. A igreja no poder do Espírito: uma contribuição à eclesiologia messiânica. Santo André: Academia Cristã, 2013. p. 147.

93 MOLTMANN, 2013, p. 147. 
promoção do Reino de Deus que não precisa, necessariamente, ser mencionado quando em contato com o outro, mas testemunhado. A Igreja entende que se trata, desde o início, do Reino. Nesse sentido, a Igreja não é o resultado da missão. Para Moltmann, “a Igreja existe como uma realidade provisória para servir como meio para a vinda do Reino universal de Deus no mundo, ou, dito de outra forma, que a Igreja existe em missão" ${ }^{94} \mathrm{~A}$ missão é a proclamação de uma esperança viva, ativa e apaixonada pelo Reino de Deus e seus valores vivenciados por Jesus conforme os evangelhos. ${ }^{95}$ Uma afirmação como essa tem implicações sociais, éticas, econômicas e políticas. Antes de ser algo doutrinário, a missão é pensada a partir do horizonte do Reino de Deus, tendo no seguimento de Jesus a práxis do testemunho.

Aqui, no nosso entender, é possível alocar a reflexão de Moltmann aos autores já mencionados, Paulo Freire e Kwok Pui-Lan. Assim como Freire, que coloca a esperança como um fundamento para o diálogo, Moltmann foca na esperança como principal elemento para a práxis enquanto oportunidade de missão. Diz ele: “a práxis da missão transformadora necessita de uma certa cosmovisão, de confiança no mundo, de esperança no mundo. Ela busca o que é real e objetivamente possível neste mundo, para apoderar-se dele e realiza-lo em direção ao futuro prometido de justiça". 96 Com essa assertiva, Moltmann, assim como Pui-Lan, indica as condições para o diálogo. Para ele, o diálogo é necessário "quando surge um conflito que ameaça a vida, e cuja solução pacífica deve ser buscada conjuntamente mediante o diálogo" ${ }^{97}$ Esse diálogo, quando em missão, se torna proveitoso porque não está se "falando sobre nós mesmos ou uns sobre os outros, mas conjuntamente sobre um terceiro assunto" .98

\section{O diálogo é a missão: por uma pauta comum entre sujeitos de fé}

Como vimos, o diálogo acontece quando há um terceiro ponto que o torne possível. Dito de outro modo, não há diálogo quando uma das partes, por exemplo, não concebe a dignidade humana como um valor em si. Há questões que são prementes na relação entre os seres humanos e estes com a natureza (ecologia). Os problemas e dificuldades se multiplicam em todo o mundo. A fome ainda é um problema sério para milhares de pessoas; o tema da cidadania continua sendo um grande desafio político, inclusive em países democráticos; a perseguição religiosa se dá em diferentes níveis, inclusive com a morte; há refugiados enfrentando travessias sem rumo porque seus países estão em guerra, mas também, em alguns casos, porque professam outra religião e, por

94 BAUCKHAM, Richard. The theology of Jürgen Moltmann. Edinburgh: T\&T Clark, 1995. p. 145.

95 MOLTMANN, Jürgen. El camino de Jesucristo: cristología en dimensiones mesiánicas. 2.ed. Salamanca: Sígueme, 2000. p. 144.

96 MOLTMANN, Jürgen. Teologia da esperança: estudos sobre os fundamentos e as consequências de uma escatologia cristã. São Paulo: Teológica, 2003. p. 342.

97 MOLTMANN, Jürgen. Experiências de reflexão teológica: caminhos e formas da teologia cristã. São Leopoldo: UNISINOS, 2004. p. 29.

98 MOLTMANN, 2004, p. 30. 
este motivo, são massacrados. ${ }^{99}$ Esses e outros problemas afetam a vida de milhões de pessoas. Quando as religiões são provocadas a uma práxis diante de situações como essas? Seriam esses os problemas que fomentariam um diálogo e, consequentemente, a missão? Sendo o diálogo a missão, quais seriam os pontos comuns?

A partir da reflexão de alguns autores, estamos inclinados a pensar que uma pauta que seja comum às religiões, fomentando assim o diálogo entre elas e a possibilidade da missão (missio Dei), seja as questões que envolvem os Direitos Humanos (DH). ${ }^{100}$ Estamos cientes de que o tema dos DH é algo recente: “a tese de que humanos possuem certos direitos básicos, fundamentais, não é óbvia e nem existiu sempre. Ela é uma criação de religiões universais que creem em um Deus transcendente que dá esses direitos a todos os seres humanos, independentemente de sua nacionalidade, crença ou condição social" . ${ }^{101}$ Embora os DH não sejam “criação de religiões universais", de maneira direta, há uma estreita relação. Essa ideia de que era possível garantir certas individualidades estava em circulação na Europa, tornando-se em algo palpável em 1789 com a Declaração dos Direitos do Homem e do Cidadão. A partir desse fato, "o reconhecimento dos direitos humanos se expandiu, tanto por meio das constituições de quase todos os Estados nacionais quanto por meio de normas internacionais, como a Declaração Universal dos Direitos Humanos, promulgada pelas Nações Unidas em 1948”. ${ }^{102}$ Com certeza, a noção de direitos individuais constituiu-se como um avanço sem precedentes na história humana. Quanto ao seu avanço em termos de medidas concretas, indubitavelmente, há sérias dificuldades. De um lado, há uma ideia de que cabe ao Estado se esforçar mais a fim de garantir a execução dos DH com eficiência. Por outro lado, não é possível esperar do mercado nenhum alívio para aqueles que lutam pela subsistência. Como bem nos lembra Jung Mo Sung, a lógica do mercado é a concorrência, ou seja, "eliminar aqueles que são incompetentes. Esperar que o mercado resolva essas questões sociais é impossível”. 103 A situação fica ainda mais complicada quando há a notória noção de que a política está estritamente dependente do mercado. Na contemporaneidade, não está sendo mais possível idealizar a política sem a bolsa de valores, as duas coisas andam juntas. Com isso, Boaventura de Sousa Santos chama atenção para a diferença entre sujeitos dos DH e discursos dos $\mathrm{DH}$, ou seja, há mais discurso sobre os $\mathrm{DH}$ e muito menos sujeitos alvos dos

99 Todos esses casos são notórios pela grande mídia. Quanto aos refugiados por razão religiosa, estamos pensando em quase 50 mil (segundo a ONU) pessoas de tradição mulçumana seguindo de Mianmar para Bangladesh, por sofrerem severos ataques por parte do exército. A primeira-ministra do país, Aung San Suu Kyi, ganhadora do Nobel da Paz, vem recebendo críticas por não intervir de maneira significativa na situação. Entre os críticos está Dalai Lama.

100 Para um panorama quanto ao desenvolvimento dos Direitos Humanos e contexto histórico: FACCHI, Alessandra. Breve história dos direitos humanos. São Paulo: Loyola, 2011.

${ }^{101}$ MO SUNG, Jung. Direitos humanos em uma era pós-humanista. Disponível em: <http://portal.metodista.br/posreligiao/noticias/jung-mo-sung-questiona-futuro-dos-direitoshumanos-em-era-pos-humanista>. Acesso em: 5 nov. 2017.

102 NINO, Carlos S. Ética e direitos humanos. São Leopoldo: UNISINOS, 2011. p. 20.

103 MO SUNG, 2017. 
DH. Por essa razão o autor indaga: “os direitos humanos servem eficazmente à luta dos excluídos, dos explorados e dos discriminados". ${ }^{104}$ As conclusões do autor são pessimistas. $\mathrm{O}$ discurso dos $\mathrm{DH}$ foram capturados por forças hegemônicas, cabendo agora fazer um caminho contra-hegemônico. Para tanto, as teologias políticas (religiões) podem contribuir.

Michael Amaladoss, quando trata da prática do diálogo inter-religioso, dedica-se a fazer uma relação entre "Religião e direitos humanos". ${ }^{105}$ Como o Estado (em menor ou maior grau, dependendo do lugar) apresenta sérias deficiências na promoção dos DH, Amaladoss elenca as dificuldades que as religiões têm com a temática dos $\mathrm{DH}$, mesmo algumas religiões não tratando dessa forma a questão, ou seja, como questão de DH e com essa noção do que seja DH no sentido ocidental, por exemplo. Ainda assim, o autor denuncia de que a Igreja Católica, sua tradição de fé, ao longo da história, resistiu à noção dos DH. O hinduísmo ainda está associado a desigualdades sistêmicas, como a divisão social baseada em castas. Os confucionistas também têm problemas com isso, quando tendem a subordinar o indivíduo ao grupo. O budismo parece estar pouco interessado na vida deste mundo e em suas estruturas, embora Dalai Lama seja uma voz audível e contestatória. $\mathrm{O}$ islã parece ignorar alguns direitos em nome da sharia, onde as mulheres sofrem mais com a "lei islâmica". ${ }^{106}$ Para o autor, as religiões, por estarem presente na vida das pessoas, têm condições de contribuir com o avanço dos DH. Para tanto, é preciso focalizar alguns problemas que são evidentes. Dentre eles, as estruturas socioeconômicas existentes. Além disso, as religiões devem assumir seu papel, livrando-se da manipulação política, mas não sendo apolítica, o que seria impossível no contexto humano. ${ }^{107}$ Como ressalta o autor, "só as religiões (...) podem proporcionar um fundamento último para os valores"108 e esse seria um ponto onde o diálogo teria êxito. A rigor, as religiões têm uma antropologia otimista. Cada uma delas detém um discurso a favor da vida.

A tradição cristã percebe a dignidade humana no ser humano enquanto imagem de Deus; os hindus veem-na na identidade não-dual profunda do ser humano com a própria Realidade; o islã vê tudo como dádiva divina; a jornada que o budismo empreende para o nirvana pondera sobre tudo que é relativo e histórico. ${ }^{109}$

Em síntese, as religiões nutrem um bem viver, ou seja, há nas suas matrizes elementos que tratam da dignidade do ser humano e suas relações com o sagrado, com outros semelhantes e com a natureza. Agora, as condições para que essas religiões

104 SOUSA SANTOS, Boaventura de. Se Deus fosse um ativista dos direitos humanos. 2.ed. São Paulo: Cortez, 2014. p. 15.

105 AMALADOSS, Michael. Pela estrada da vida: prática do diálogo inter-religioso. São Paulo: Paulinas, 1995. p. 199-218.

106 AMALADOSS, 1995, p. 200.

107 AMALADOSS, 1995, p. 206.

108 AMALADOSS, 1995, p. 210.

109 AMALADOSS, 1995, p. 210. 
dialoguem e tratem de temas comuns, não passa, necessariamente, pelo aspecto dogmático ou doutrinário das religiões. Para Amaladoss, essa discussão não contribuiria. $\mathrm{O}$ aspecto ético das religiões seria um ponto comum, podendo "haver convergência para uma ação comum na defesa de valores humanos e espirituais". 110 Obviamente as religiões abrigam suas ambiguidades em termos de discurso e prática, 111 mas, ainda assim, há, nas estruturas religiosas, uma vocação/convocação para o acolhimento do humano.

Quando se propõe o diálogo inter-religioso, e tendo a missão como promotora deste, surge a pergunta: e a questão soteriológica? Esse é um debate que poderia ser tratado em outro momento, por ser complexo e exigir espaço para o seu desenvolvimento em diferentes olhares. ${ }^{112}$ Aqui, essa questão quanto à salvação nas diferentes religiões não seria interessante, uma vez que o tema está no âmbito teológico-doutrinário das religiões. Estamos de acordo com Amaladoss, quando diz que "o diálogo inter-religioso deve descolar-se (...) da discussão teológica para a profecia, num desafio conjunto às estruturas socioculturais e políticas opressivas". ${ }^{113}$ É nesse sentido que pontuamos o diálogo como missão. A missão parte de uma lúcida reflexão e percepção de que há forças impeditivas da promoção humana. Essas forças estão articuladas e detêm aparato político, jurídico e, principalmente, econômico, a fim de continuar perpetuando condições desiguais entre as pessoas, principalmente os menos favorecidos. A missão, quando mediada pelo diálogo em torno de temas que sejam comum, precisa focar em serviço na direção do outro, mas também em compaixão diante do sofrimento humano e, assim, promover formas de contestação do status quo que privilegia situações de injustiça. ${ }^{114}$

\section{Referências}

AMALADOSS, Michael. Pela estrada da vida: prática do diálogo inter-religioso. São Paulo: Paulinas, 1995.

AZEVEDO, Marcello de Carvalho. Modernidade e cristianismo: o desafio à inculturação. São Paulo: Loyola, 1981.

BAUCKHAM, Richard. The theology of Jürgen Moltmann. Edinburgh: T\&T Clark, 1995.

BOFF, Leonardo. América Latina: da conquista à nova evangelização. 3.ed. São Paulo: Ática, 1992.

110 AMALADOSS, 1995, p. 216.

111 Quanto às distâncias entre o discurso e a prática das principais religiões em relação aos Direitos Humanos: TAMAYO, Juan J. Fundamentalismos y diálogo entre religiones. 2.ed. Madrid: Trotta, 2009. p. 205274.

112 Para uma percepção de "salvação" a partir do pluralismo religioso: HIGUET, Etienne A. Fora das religiões não há salvação: salvação em uma perspectiva pluralista. In: TOMITA, Luiza E. et al. (Orgs.). Teologia latino-americana pluralista da libertação. São Paulo: Paulinas, 2006. p. 191-218.

113 AMALADOSS, 1995, p. 218.

114 RIBEIRO, Claudio. Religião, democracia e direitos humanos: presença pública inter-religiosa no fortalecimento da democracia e na defesa dos direitos humanos no Brasil. São Paulo: Reflexão, 2016. p. 45. 
BOSCH, David J. Missão transformadora: mudanças de paradigma na teologia da missão. 3.ed. São Leopoldo: Sinodal, 2009.

CALDAS, Carlos. O último missionário. São Paulo: Mundo Cristão, 2001.

CUNHA, Magali. Pluralismo religioso na agenda das igrejas protestantes no mundo contemporâneo. In: BHOGAL, Inderjit S. Pluralismo religioso e a missão da igreja na atualidade. São Bernardo do Campo: EDITEO, 2007.

DUPUIS, Jacques. O cristianismo e as religiões: do desencontro ao encontro. São Paulo: Loyola, 2004.

. Rumo a uma teologia cristã do pluralismo religioso. São Paulo: Paulinas, 1999.

FACCHI, Alessandra. Breve história dos direitos humanos. São Paulo: Loyola, 2011.

FORNET-BETANCOURT, Raúl. Religião e interculturalidade. São Leopoldo: Sinodal, 2007.

FREIRE, Paulo. Pedagogia do oprimido. 50.ed. Rio de Janeiro: Paz e Terra, 2011.

GEFFRÉ, Claude. A fé na era do pluralismo religioso. In: TEIXEIRA, Faustino (Org.). Diálogo de pássaros: nos caminhos do diálogo inter-religioso. São Paulo: Paulinas, 1993.

. De Babel a Pentecostes: ensaios de teologia inter-religiosa. São Paulo: Paulus, 2013.

HIGUET, Etienne A. Fora das religiões não há salvação: salvação em uma perspectiva pluralista. In: TOMITA, Luiza E. et al. (Orgs.). Teologia latino-americana pluralista da libertação. São Paulo: Paulinas, 2006.

KNITTER, Paul. “A transformação da missão no paradigma pluralista”, Concilium, n. 319, $2007 / 1$.

LIENEMANN-PERRIN, Christine. Missão e diálogo inter-religioso. São Leopoldo: Sinodal, 2005.

MIRANDA, Mario de França. Inculturação da fé: uma abordagem teológica. São Paulo: Loyola, 2001.

MO SUNG, Jung. Direitos humanos em uma era pós-humanista. Disponível em:

<http:// portal.metodista.br/posreligiao/noticias/jung-mo-sung-questiona-futuro-dosdireitos-humanos-em-era-pos-humanista>. Acesso em: 5 nov. 2017.

MOLTMANN, Jürgen. A fonte da vida: o Espírito Santo e a teologia da vida. São Paulo: Loyola, 2002.

. A igreja no poder do Espírito: uma contribuição à eclesiologia messiânica. Santo André: Academia Cristã, 2013.

El camino de Jesucristo: cristología en dimensiones mesiánicas. 2.ed. Salamanca:

Sígueme, 2000.

Protestantismo em Revista | São Leopoldo | v. 44, n. 01 | p. 266-291| jan./jun. 2018

Disponível em: <http://periodicos.est.edu.br/index.php/nepp> 
. Experiências de reflexão teológica: caminhos e formas da teologia cristã. São

Leopoldo: UNISINOS, 2004.

. Teologia da esperança: estudos sobre os fundamentos e as consequências de uma escatologia cristã. São Paulo: Teológica, 2003.

NASCIMENTO, Analzira. Evangelização ou colonização?: o risco de fazer missão sem se importar com o outro. Viçosa: Ultimato, 2015.

NINO, Carlos S. Ética e direitos humanos. São Leopoldo: UNISINOS, 2011.

OLIVEIRA, David M. Diálogo e missão nos Andes: um estudo de teologia da missão latinoamericana. São Paulo: Reflexão, 2017.

PIEDRA, Arturo. Evangelização protestante na América Latina: análises das razões que justificaram e promoveram a expansão protestante (1830-1960). São Leopoldo: Sinodal, 2006. v. 1.

PUI-LAN, Kwok. Globalização, gênero e construção da paz: o futuro do diálogo interfé. São Paulo: Paulus, 2015.

RIBEIRO, Claudio. Religião, democracia e direitos humanos: presença pública inter-religiosa no fortalecimento da democracia e na defesa dos direitos humanos no Brasil. São Paulo: Reflexão, 2016.

; CUNHA, Magali. O rosto ecumênico de Deus: reflexões sobre ecumenismo e paz. São Paulo: Fonte Editorial, 2013.

; SOUZA, Daniel. A teologia das religiões em foco: um guia para visionários. São Paulo: Paulinas, 2012.

SANTOS, Noêmia. Por uma educação libertadora: pedagogia dialógica a partir de Paulo Freire e Juan Luis Segundo. São Paulo: Fonte Editorial, 2012.

SILVA, Sílvia R. L. Identidade, unidade e missão: des-colonização e cuidado, paradigmas da missão. In: GIESE, Nilton (Org.). Missão e evangelização na América Latina e Caribe. São Leopoldo: Sinodal, 2012.

SOUSA SANTOS, Boaventura de. Se Deus fosse um ativista dos direitos humanos. 2.ed. São Paulo: Cortez, 2014.

SUESS, Paulo. Pluralismo e missão: por uma hermenêutica da alteridade. In: VIGIL, José Maria et al. (Orgs.). Teologia pluralista libertadora intercontinental. São Paulo: Paulinas, 2008.

TAMAYO, Juan J. Fundamentalismos y diálogo entre religiones. 2.ed. Madrid: Trotta, 2009.

TEIXEIRA, Faustino. Cristianismo e diálogo inter-religioso. São Paulo: Fonte Editorial, 2014. . Inculturação da fé e pluralismo religioso. In: TAVARES, Sinivaldo S. (Org.). Inculturação da fé. Petrópolis: Vozes, 2001. 
. Teologia das religiões: uma visão panorâmica. São Paulo: Paulinas, 1995.

. Teologia das religiões: uma visão panorâmica. São Paulo: Paulinas, 1995.

TODOROV, Tzvetan. A conquista da América: a questão do outro. 4.ed. São Paulo: Martins Fontes, 2011.

VIGIL, José M. Teologia do pluralismo religioso: para uma releitura pluralista do cristianismo. São Paulo: Paulus, 2006.

WALIGGO, John. Inculturação. In: LOSSKY, Nicholas et al. (Eds.). Dicionário do movimento ecumênico. Petrópolis: Vozes, 2005.

WIRTH, Lauri E. Protestantismos latino-americanos: entre o imaginário eurocêntrico e as culturas locais. In: FERREIRA, João C. L. (Org.). Novas perspectivas sobre o protestantismo brasileiro. São Paulo: Fonte Editorial/Paulinas, 2009.

ZWETSCH, Roberto. Inculturação. In: BORTOLLETO FILHO, Fernando (Ed.). Dicionário brasileiro de teologia. São Paulo: ASTE, 2008. 